засобів. У наші часи у процесі масового навчання папір і олівець або ручка, дошка $\mathrm{i}$ крейда служать людині для передачі інформації. Однак в останні десятиліття в умовах прискорених темпів розвитку науки і техніки ці засоби інформації не можуть задовольнити потреби підвищення ефективності навчання. Випробним методом підвищення ефективності навчального процесу $\epsilon$ наочність у навчанні: різноманітність форм і прийомів, демонстрацій різних фізичних процесів і технічних пристроїв. Наочність особливо важлива під час вивчення таких дисциплін, у яких аналізується принцип дії й конфігурації складних машин і пристроїв, розглядаються швидкоплинні в часі процеси, а також під час вивчення розділів, які містять абстрактні поняття і багатообразну символіку. До таких дисциплін відносять електроенергетичні й електротехнічні. Комплексне використання технічних засобів навчання збільшує інформаційну насиченість лекцій, сприяє глибокому засвоєнню матеріалу, підвищує ефективність педагогічної праці.

Методологія виконання лабораторних занять 3 курсу «Практикум електромонтажних робіт» із використанням сюжетів міжпредметніх зв'язків багато в чому краще сприймається студентами. Практичне застосування цього методу студентами під час збирання монтажних схем показало його ефективність під час навчання.

Це тільки приклад того, що не певні технічні пристрої, а самі принципи автоматизації можуть бути покладені в основу методик навчання та програм, що розробляються.

Отже, методика навчання автоматизації повинна грунтуватися на алгоритмізації поставлених педагогічних завдань, на базі систем штучного інтелекту, оволодіння інформаційними технологіями, зокрема мережі Інтернет (iї використання $\epsilon$ необхідною умовою під час самостійного, індивідуального навчання); процес самостійного навчання може передбачати навчальні програми, що супроводжуються звуковим супроводом 3 контрольними завданнями у вигляді тестів, узагальнення інформації, звернення до викладача за роз'ясненням того або того питання, а також підготовка рефератів і їх обговорення на колоквіумі. Наведена методика засвідчує значно збільшені показники рівня зацікавленості студентів і доцільність використання сюжетів міжпредметних зв'язків майже на всіх етапах навчання електротехнічних дисциплін.

\title{
Література
}

1. Камнев В. Н. Чтение схем и чертежей електроустановок : [учеб. пособ. для ПТУ] / В. Н. Камнев. - М. : Высшая школа, 1986. - 144 с. 2. Атутов П. Р. Связь трудового обучения с основами наук / П. Р. Атутов. - М. : Просвещение, 1983. - 126 с.

\section{ПРОБЛЕМА ПРОФЕСІЙНОЇ ПІДГОТОВКИ МАЙБУТНІХ УЧИТЕЛІВ МУЗИЧНОГО МИСТЕЦТВА ДО ВОКАЛЬНО-ПЕДАГОГІЧНОЇ ДІЯЛЬНОСТІ В ТЕОРЇ̈ НАВЧАННЯ}

Овчаренко Н. А. Проблема професійної підготовки майбутніх учителів музичного мистецтва до вокально-педагогічної діяльності в теорії навчання.

У статті розглянуто актуальну проблему професійної підготовки майбутніх учителів музичного мистецтва до вокально-педагогічної діяльності в теорії навчання. На основі аналізу науково-теоретичного досвіду подано класифікацію наукових праць та характеристику основних напрямків із проблеми дослідження. 
Ключові слова: професійна підготовка, майбутній учитель музичного мистецтва, вокально-педагогічна діяльність, педагогічна теорія.

Овчаренко Н. А. Проблема профессиональной подготовки будущих учителей музыкального искусства к вокально-педагогической деятельности в теории обучения.

В статье рассматривается актуальная проблема профессиональной подготовки будущих учителей музыкального искусства к вокально-педагогической деятельности в теории обучения. На основе анализа научно-теоретического опыта предлагается классификация научных трудов и характеристика основных направлений по проблеме исследования.

Ключевые слова: профессиональная подготовка, будущий учитель музыкального искусства, вокально-педагогическая деятельность, педагогическая теория.

Ovcharenko N. A. The issue of professional training of future music art teachers for vocal pedagogical activity in pedagogical theory.

The article deals with important issues concerning professional training of future music art teacher for vocal pedagogical activity in pedagogical theory. As a result of scholarly and theoretical experience the author suggests the classification of the scientific works and characteristics of the main aspects of research.

Key words : professional training, future music art teacher, vocal and pedagogical activity, pedagogical theory.

Розв’язання проблеми професійної підготовки майбутніх учителів музичного мистецтва до вокально-педагогічної діяльності значною мірою залежить від грунтовного вивчення накопиченого педагогічного досвіду. Актуальність такого аналітичного дослідження зумовлена тим, що в українській мистецько-педагогічній думці накопичилась значна кількість наукових праць, присвячених окремим аспектам вокального мистецтва, вокальної педагогіки, які необхідно враховувати для вирішення питання професійної підготовки майбутніх фахівців до вокальнопедагогічної діяльності як цілісної багатовидової структури. Особливого значення набуває питання класифікації наукових досліджень у сфері професійної підготовки майбутніх учителів музичного мистецтва до вокально-педагогічної діяльності. За характеристикою класифікацій, презентованих у наукових працях, можливо визначити, які проблеми вже знайшли своє розв'язання у професійній підготовці майбутніх учителів музичного мистецтва до вокально-педагогічної діяльності, а які ще потребують свого вирішення.

У сучасних дослідженнях мистецтвознавства та мистецької педагогіки науковці здійснюють спроби класифікації наукових та науково-методичних праць 3 окремих аспектів вокального мистецтва та вокальної педагогіки. Приклади такої класифікації відображені в дисертаційних дослідженнях сучасних мистецтвознавців (О. Єрошенко, В. Михайлець, Ї. Чжан), які здебільшого висвітлюють історичні, культурологічні, музично-естетичні, жанрово-стильові, виконавські питання сфери вокального мистецтва. Так, у вивченні історичного і теоретичного аспектів вокальної основи хорового мистецтва В. Михайлець послуговувалася такої класифікацією: праці, які сприяли визначенню історико-культурологічної традиції вітчизняного хорового співу; праці представників вітчизняного хорознавства, теорії та методики вокалу; праці, у яких висвітлено методи і положення експериментально-теоретичного вивчення феномену вокальної техніки [4]. О. Єрошенко, досліджуючи музично-естетичний та виконавський аспекти емоційної сфери у вокальній творчості, класифікує наукові 
праці, що відображають: історію та теорію вокального мистецтва; теоретичну спадщину видатних вокальних педагогів; матеріали наукових досягнень представників російської вокальної школи та репрезентів зарубіжних вокальних шкіл; спогади, літературну та епістолярну спадщину видатних співаків; інші вітчизняні й зарубіжні довідкові та енциклопедичні відомості [2, с. 3]. Висвітлюючи вокальнопедагогічну творчість як основу виконавської діяльності співака, Ї. Чжан класифікує фундаментальні праці з теорії вокального мистецтва як такі, що розкривають: техніку постановки голосу 3 фізіологічної позиції; проблему формування професійних здібностей; підготовку професійного співака до виконавської діяльності; методичний та творчий педагогічний досвід [6].

Серед широкого спектру проблем, які розглядаються авторами в теорії мистецтвознавства, більшість спрямовано на дослідження вокального мистецтва та вокально-виконавського виду діяльності.

Mema cmammi-здійснити класифікацію наукових праць та охарактеризувати основні напрями досліджень із проблеми професійної підготовки майбутніх учителів музичного мистецтва до вокально-педагогічної діяльності.

У сучасних дисертаціях класифікація наукових праць 3 проблеми професійної підготовки майбутніх учителів музичного мистецтва до вокально-педагогічної діяльності здійснюється відповідно до предмета дослідження. Так, досліджуючи взаємодію вокального і методичного компонентів у процесі професійної підготовки майбутнього вчителя музики, Л. Василенко класифікує праці, у яких: визначаються принципи вокальної підготовки на основі використання фонетичного та фонопедичного методів; висвітлюється процес виховання естетичного ставлення до вокального мистецтва; досліджуються умови удосконалення вокально-педагогічної підготовки майбутніх спеціалістів; акцентується увага на формуванні вокальномовленнєвої культури вчителя музики; розкривається специфіка опрацювання шкільного репертуару в процесі вокального навчання; надається педагогічне обгрунтування змісту вокальної підготовки та формуванню професійно значущих якостей у процесі вокальної підготовки [1]. Окреслюючи шляхи розв'язання проблеми формування вокально-слухових навичок майбутнього вчителя музики, О. Маруфенко застосовує таку класифікацію праць: роботи 3 методики постановки голосу та фізіології співацького процесу; присвячені біофізичним основам співацького процесу; які відображають формування та розвиток співацьких здібностей [3, с. 1]. Розроблюючи методику формування вокальної компетентності майбутніх учителів музики, Лі Чуньпен застосовує таку класифікацію досліджень: праці, присвячені теорії виховання вокальних навичок; системно-цілісному аналізу педагогічної спадщини майстрів вокального мистецтва; вокальній педагогіці як структурному складнику загальної педагогіки [7, с. 3]. Вивчаючи методику розвитку творчих здібностей майбутнього вчителя музики в процесі вокальної підготовки, Г. Панченко класифікує науково-методичні праці так: роботи 3 методики постановки голосу та фізіології співацького процесу; формування та розвиток співацьких здібностей; специфіка вокальної роботи з учнями; формування вокально-слухових навичок та професійно-значущих якостей майбутнього вчителя; взаємодія вокального та методичного компонентів у структурі професійної підготовки студентів музичнопедагогічних факультетів [5].

Спільним у класифікації наукових праць із вокального мистецтва та вокальної педагогіки $є$ те, що дослідники аналізують праці, у яких розглянуть окремі аспекти вокально-педагогічної діяльності. Недостатньо висвітленою лишається проблема формування цілісної структури вокально-педагогічної діяльності вчителя музичного 
мистецтва, що передбачає посилення семіотично-герменевтичного та аксіологічнокультурологічного складників такої діяльності i, на основі розгляду музичної та поетичної мови вокального твору, засвоєння цінностей вокального мистецтва. Зважаючи, що для розв'язання такої проблеми $є$ необхідним цілісне дослідження наукової думки, яке не претендує на повний огляд праць, можемо класифікувати наукові праці за такими напрямами:

До першого напряму відносимо фундаментальні дослідження, у яких подано загальні основи історії, теорії вокального мистецтва та вокальної педагогіки, зокрема: історія та етапи становлення української вокально-виконавської та вокальнопедагогічної школи (В. Антонюк, Б. Гнидь, Ю. Грищенко); вища нервова діяльність і анатомофізіологія процесу співу (І. Левідова, Ф. Засєдателєва, І. Павлова, Л. Работнова, І. Сеченова); акустика та звукоутворення у процесі постановки голосу (Л. Дмитрієва, В. Морозова, Р. Юссона); технічний розвиток голосу (Д. Свтушенко, М. Єгоричева, А. Кулієва, К. Плужніков, В. Юшманов); вокально-виконавська творчість, теоретичні та практичні аспекти вокальної педагогіки (В. Антонюк, Н. Гребенюк, Л. Дмитрієв, Д. Свтушенко, О. Стахевич, П. Троніна); охорона та гігієна співацького голосу (Л. Дмитрієв, В. Смельянов, Г. Пустинніков). Такі наукові та навчально-методичні праці висвітлюють основні питання та загальні основ історії, теорії вокального мистецтва, вокальної педагогіки. Сучасним науковим дослідженням за таким напрямом притаманне вивчення та визначення різних історичних періодів становлення національної вокально-педагогічної школи, інтегративний підхід до використання здобутків світових вокальних шкіл, пошук нових теорій і методів удосконалення науки про голос та процесу виховання професійного співака, педагога вокалу.

До другого напряму входять дослідження, у яких висвітлено сучасні освітні парадигми, концепції, методологічні підходи професійної підготовки майбутніх учителів музичного мистецтва до вокально-педагогічної діяльності (Т. Жигінас, Т. Ткаченко, Чен Дін). Питання освітніх парадигм, концепцій мистецької освіти постійно знаходяться у полі зору сучасних дослідників. Однак, методологічні засади професійної підготовки майбутніх учителів музичного мистецтва до вокальнопедагогічної діяльності є недостатньо висвітленими у наукових працях.

Третій напрям складають наукові розвідки, у яких відображено сучасні шляхи зближення теорій вокального виконавства i музикознавства (Н. Даньшина, С. Кудринецький, Го Суншан, О. Стахевича, О. Філатова, Ї. Чжан). У наукових працях такого напряму відображено зближення теорій вокального виконавства, вокальної педагогіки і музикознавства, здійснено пошукову роботу щодо осягнення художніх смислів вокальних творів на основі поглибленого розуміння жанрово-стильових особливостей вокальної музики різних епох. Дослідження надають можливість майбутнім учителям музичного мистецтва сформувати вміння мистецького діалогу, здійснити аналітичну роботу для усвідомлення специфіки музичної мови, музичних та специфічно вокально-виконавських засобів виразності; зануритись у художньо-образний світ вокального мистецтва, віднайти необхідні виконавські та педагогічні методи опанування вокальним твором.

До четвертого напряму відносимо праці, у яких розглянуто роль та значення вокально-педагогічної діяльності в контексті фахової підготовки майбутнього вчителя музичного мистецтва (Л. Арчажнікова, Н. Добровольська, О. Олексюк, В. Попов). Дослідження за таким напрямом вказують на специфіку вокально-педагогічної роботи вчителя музичного мистецтва, що передбачає: володіння ним навчальним матеріалом за програмою, методикою постановки голосу, знаннями особливостей роботи з хором, 
ансамблем, солістом та іншими.

До п'ятого напряму входять дослідження, присвячені проблемі професійної підготовки майбутніх учителів музичного мистецтва до окремих компонентів вокально-педагогічної діяльності: теоретико-аналітичного, виконавського, педагогічного (зокрема, методичного), інтерпретаційного (Л. Василенко, Л. Лабінцева, О. Прядко, Г. Стасько, Г. Стулова, В. Цзяньшу). У працях такого напряму грунтовно висвітлено проблеми професійної підготовки майбутніх учителів музичного мистецтва до окремих компонентів вокально-педагогічної діяльності: теоретико-аналітичного, виконавського, педагогічного недостатнє висвітлення питань у теорії мистецької педагогіки. Проте поліаспектна структура вокально-педагогічної роботи вчителя музичного мистецтва та, відповідно, його професійна підготовка у вищому навчальному закладі до різних спрямувань майбутньої діяльності лишається нерозробленою в науковій теорії.

Шостий напрям складають наукові праці, спрямовані на формування вокальнопедагогічної компетентності майбутніх учителів музичного мистецтва (Ч. Дін, Н. Можайкіна, Т. Ткаченко). Розгляд праць такого напряму показав, що у вітчизняній науковій думці тільки розпочинається розроблення систем мистецько-педагогічних компетенцій вчителя музичного мистецтва, що передбачає і визначення системи вокально-педагогічних компетенцій фахівція, яка забезпечить формування його готовності до професійної вокально-педагогічної діяльності.

До сьомого напряму відносять праці, спрямовані на формування вокальнопедагогічної культури та вокально-педагогічних цінностей і ціннісних орієнтацій майбутніх учителів музичного мистецтва (В. Антонюк, К. Кабриль, Ван Цзяньшу). Вокально-педагогічна культура вчителя, як системне утворення, $\epsilon$ предметом дослідження багатьох наукових досліджень у сфері мистецької педагогіки. Однак, проблеми формування вокально-педагогічних цінностей та ціннісних орієнтацій майбутніх учителів музичного мистецтва ще тільки починають розглядатися у науковій мистецтвознавчій та педагогічній думці, що потребує подальшого вивчення і досліджень.

До восьмого напряму входять дослідження, у яких розкрито питання розвитку професійно-особистісних якостей майбутнього вчителя музичного мистецтва у процесі вокально-педагогічної діяльності та його вдосконалення протягом життя (О. Маруфенко, Г. Панченко, Г. Стасько, Т. Ткаченко, Ю. Юцевич, Ма Цзюнь, Ю. Юцевич). У наукових працях за таким напрямом висвітлено питання впливу професійної підготовки майбутніх учителів музичного мистецтва до вокальнопедагогічної діяльності на становлення їхніх професійно-особистісних якостей, обгрунтовано методики розвитку загальних, мистецько-творчих, вокальних здібностей у процесі такої підготовки.

Отже, аналіз наукових та науково-методичних праць надав змогу класифікувати наукові праці та визначити та характеризувати основні вісім напрямів наукових дослідження за окресленою проблемою професійної підготовки майбутніх учителів музичного мистецтва до вокально-педагогічної діяльності.

\section{Література}

1. Василенко Л. М. Взаємодія вокального і методичного компонентів у процесі професійної підготовки майбутнього вчителя музики: автореф. на здобуття наукового ступеня канд. пед. наук: спец. 13.00.02 «Теорія та методика навчання музики i музичного виховання»/ Л. М. Василенко. - $\quad$ К., $2003 .-23$ с. 2. Єрошенко О. В. Емоційна сфера у вокальній творчості: музично-естетичні та виконавські аспекти: автореф. дисертації на здобуття наукового ступеня кандидата 
мист-ва: 17.00.03 «Музичне мистецтво»/ О. В. Срошенко. - Харків, 2008. - 19 с. 3. Маруфенко О. В. Формування вокально-слухових навичок майбутнього вчителя музики: дис. ... канд. пед. наук: спец. 13.00.02 «Теорія та методика навчання музики і музичного виховання»/ Олена Вікторівна Маруфенко. - К., 2006. - 265 с. 4. Михайлець В. В. Вокальна основа хорового мистецтва: історичний та теоретичний аспекти: автореф. дисертації на здобуття наукового ступеню кандидата мист-ва: 17.00 .03 «Музичне мистецтво»/ В. В. Михайлець. - Одеса., 2004. - 18 с. 5. Панченко Г. П. Методика розвитку творчих здібностей майбутнього вчителя музики в процесі вокальної підготовки: автореф. дис. на здобуття наукового ступеня канд. пед. наук: спец. 13.00.02 «Теорія та методика навчання музики і музичного виховання» / Г. П. Панченко. - К., 2008. - 24 с. 6. Чжан Ї. Вокально-педагогічна творчість як передумова виконавської діяльності співака: автореф. дис. на здобуття наукового ступеня канд. мистецтвознавства: 17.00 .03 «Музичне мистецтво»/ Ї. Чжан. - Одеса, 2006. - 18 с. 7. Чуньпен Лі. Методика формування вокальної компетентності майбутніх учителів музики: автореф. дис. на здобуття наукового ступеня канд. пед. наук: спец. 13.00.02 «Теорія та методика навчання музики i музичного виховання» / Лі Чуньпен. - К., 2013. - 20 с.

УДК 371.15

Ірина Пальикова

\section{ПІДГОТОВКА ВЧИТЕЛЯ В КОНТЕКСТІ СУЧАСНОЇ ГУМАНІСТИЧНОЇ ОСВІТНЬОЇ ПАРАДИГМИ}

Пальшкова І. О. Підготовка вчителя в контексті сучасної гуманістичної освітньої парадигми.

Гуманна спрямованість змісту освіти у вищий школі реалізується через комплексний розвиток особистості засобами педагогічних дисциплін, забезпечується системою педагогічних умов, з-поміж яких: створення ситуацій успіху в пізнавальній діяльності; реалізація диференційованого підходу до побудови змісту навчальної роботи студентів; організація групових форм пізнавальної діяльності на основі співтворчості та співпраці у системі «викладач - студент»; залучення учнів до участі в пізнавальних іграх, розроблених на основі актуального матеріалу.

Ключові слова: гуманізація, підготовка вчителя, система «викладач - студент», гуманістична освітня парадигма, пізнавальні ігри.

Пальшкова И. А. Подготовка учителя в контексте современной гуманистической образовательной парадигмы.

Гуманная направленность содержания образования в высший школе реализуется через комплексное развитие личности средствами педагогических дисциплин, обеспечивается системой педагогических условий, среди которых: создание ситуаций успеха в познавательной деятельности; реализация дифференцированного подхода к построению содержания учебной работы студентов; организация групповых форм познавательной деятельности на основе сотворчества и сотрудничества в системе «преподаватель - студент»; включение учеников в познавательные игры, разработанных на основе актуального материала.

Ключевые слова: гуманизация, подготовка учителя, система «преподаватель студент», гуманистическая образовательная парадигма, познавательные игры. 